\title{
ANALGESIA FOR SURGICAL PROCEDURES PERFORMED ON CONSCIOUS PATIENTS*
}

\author{
Ronald R. TASKeR, M.D., F.R.C.S.(C), AND Brian M. MARShlall, M.D., F.R.C.P.(c)
}

THERE ARE certain surgical procedures preferably, of indeed necessarily, performed with the patient conscious and co-operative. Despite local anaesthesia these may become an ordeal because of the duration, associated stress, or impractibility of achieving or maintaining adequate local analgesia. Such is the case with stereotactic surgery, where not only is the patient's co-operation essential, but also his dyskinetic movements require preservation. The $2-5$-hour procedure includes the making of a burr hole, application of the frame to the external auditory canals and then to the skull, pneumo-encephalography, depth recording, brain stimulation, fractional encephalotomy, and finally wound closure.

When conventional methods of analgesia proved disappointing, attention was turned to the technique of neuroleptanalgesia ${ }^{1,2}$ so widely used in Europe. The combination of a neuroleptic drug with one of the recently synthesized narcotics, ${ }^{3}$ whose analgesic properties (up to 500 times that of morphine) far exceed toxicity, has enabled the performance of any surgical procedure on a fully co-operative conscious, or else lightly $\left(\mathbb{N}_{2} \mathrm{O}\right)$ anaesthetized, patient. In the experience described in the literature, neuroleptanalgesia was combined with endotracheal intubation and controlled or assisted ventilation. In these cases the narcotic dosage had been increased towards total analgesia, with resultant severe respiratory depression.

The present paper presents experience with a modified neuroleptanalgesia technique, whereby the use of a moderate dosage of narcotic secures useful, though not total, analgesia. With this method the degree of respiratory depression is sufficiently small to obviate intubation. The technique described is now routine for stereoencephalotomies in these units.

\section{TECHNIQUE}

In the present study, phenoperidine, $\nmid$ a narcotic with a short, intense, rapid analgesic action, 75 times that of morphine, was used. An initial dose of 1.0-1.2 mg. per $100 \mathrm{lb}$. body weight given into an intravenous drip was supplemented during the first hour of the procedure by a similar dosage divided evenly into approximately four parts, and thereafter as necessary, titrating the amount to anticipate the patient's needs. Between 15 and 30 minutes was allowed for the

From Department of Surgery, University of Toronto; Division of Neurosurgery, Toronto General Hospital; Neurosurgical Unit, Sunnybrook Hospital; and Department of Anaesthesia, University of Toronto and Toronto General Hospital. Presented at the 33rd Annual Meeting of the Royal College of Physicians and Surgeons of Canada, Quebec City, January 17, 1964.

TDl-1-phenyl-3 (4-carbethoxy-4-phenyl-piperidine)-propanol hydrochloride purchased from the laboratory of C. Janssen, Beerse, Belgium. 
development of peak analgesia. It was subsequently found that division of the initial dose into fractions of $0.4 \mathrm{mg}$. given over a $15-20$ minute interval greatly reduced respiratory depression. With this technique total doses for the entire procedure ranged up to $5.5 \mathrm{mg}$. phenoperidine compared to $8-50 \mathrm{mg}$. in conventional neuroleptanalgesia.

The neuroleptic used initially was haloperidol." This was later replaced by droperidol $\uparrow$ because of the reported occasional occurrence of certain psychic disturbances $^{2}$ after the intake of large doses of haloperidol. For the same reasons, dosages of haloperidol were always kept low-2.5 mg. I.V. at first, 1.0 or $1.25 \mathrm{mg}$. I.V. subsequently. Initially $1.25 \mathrm{mg}$. droperidol was used intravenously, but the dose was increased to $2.5 \mathrm{mg}$. I.V., plus $2.5 \mathrm{mg}$. I.M. The drug was given as the sole preoperative medication one hour prior to surgery.

\section{Results}

\section{Preliminary}

For introductory experience haloperidol and phenoperidine were used as sole medication for 14 consecutive percutaneous carotid arteriograms. The usual effect was striking analgesia without serious respiratory depression or other untoward effect.

\section{Stereotactic Surgery}

The technique was then used with 53 consecutive sterectactic procedures performed chiefly for dyskinesia. The age grouping is given in Table $\mathbb{I}$, and the patients varied from fully active, employed persons, to bed-ridden invalids. Table II gives the final dosage schedules arrived at, and now used routinely.

TABLE $\mathbb{I}$

53 Stereotactic Operations with Modified Neuroleptanalgesia

\begin{tabular}{cc}
\hline Age, yr. & No. \\
\hline Under 20 & 2 \\
$21-30$ & 5 \\
$31-40$ & 1 \\
$41-50$ & 10 \\
$51-60$ & 26 \\
Over 60 & 9 \\
\hline
\end{tabular}

\section{Analgesia}

The difficult task of assessing analgesia was attempted by combining the observations of the anaesthetist and surgeon with the experience of the patient. The degree of analgesia achieved in each case was graded increasing from 0 to 5 . Total analgesia was neither expected nor achieved, although the skin incision without the routinely used local anaesthetic was often possible. Table III summarizes the results. One case was unassessed.

'4'-Fluoro-4 (1[4-hydroxy-4(4'-chloro)-phenyl piperidino]) butyrophenone, kindly supplied by McNeil Laboratories of Canada Ltd.

†Dehydrobenzperidol-4'-4luoro-4-[N-4's-(N-benzimidazolono)- $\Delta 3,4$-tetrahydropiperidine $]$-butyrophenone hydrate; also supplied by McNeil Laboratories. 
Factors influencing analgesia were studied. Table IV shows the relation between analgesia and initial dose of phenoperidine. This demonstrates a relationship between low dosage and poor analgesia.

Analgesia was not affected by using divided doses of phenoperidine rather than a single initial dose, as shown in Table $V$. There was slight evidence that the use of droperidol, particularly in larger doses, afforded better analgesia than did haloperidol.

TABLE II

Neuroleptanalgesia Technique

\begin{tabular}{|c|c|}
\hline Droperidol & $\begin{array}{l}\left.\begin{array}{l}2.5-5.0+\mathrm{mg} . \mathbb{I} . \mathrm{V} . \\
2.5 \mathrm{mg} . \mathrm{I} . \mathrm{M} .\end{array}\right\} \| \text { hour preop. }\end{array}$ \\
\hline Phenoperidine & $\begin{array}{l}1.1-1.2 \mathrm{mg} . \text { per } 100 \mathrm{lb} \text {. in } 0.4 \mathrm{mg} \text {. aliquots } \\
\text { over } 15-20 \text { min. } \\
15-20 \mathrm{~min} \text {. before incision } \\
+ \text { same over } 1 \mathrm{st} \text { hour in } 4 \text { parts } \\
+\frac{1}{4} \text { initial dose p.r.n. }\end{array}$ \\
\hline
\end{tabular}

TABLE III

Analgiesia: 53 Stereotactic Operations

\begin{tabular}{lc} 
& No. of cases \\
\hline Excellent & 26 \\
Good & 14 \\
Fair & 8 \\
Poor & 4 \\
\hline
\end{tabular}

TABLE IV

Analgesia and Initial Dose Phenoperidine

\begin{tabular}{|c|c|c|c|}
\hline \multirow{2}{*}{$\begin{array}{c}\text { Initial } \\
\text { dose, } \\
\text { mg./100 lb. }\end{array}$} & \multicolumn{3}{|c|}{ Analgesia- $\%$ patients } \\
\hline & $\begin{array}{l}\text { Good or } \\
\text { excellent }\end{array}$ & Fair & Poor \\
\hline 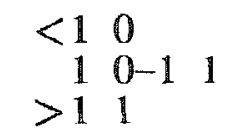 & $\begin{array}{l}80 \\
76 \\
75\end{array}$ & $\begin{array}{r}0 \\
18 \\
25\end{array}$ & $\begin{array}{r}20 \\
6 \\
0\end{array}$ \\
\hline
\end{tabular}

TABLE V

Analgesia and Phenoperidine Dosage

\begin{tabular}{lccr}
\hline \hline & \multicolumn{3}{c}{ Analgesia_\% patients } \\
\cline { 2 - 4 } & $\begin{array}{c}\text { Good or } \\
\text { excellent }\end{array}$ & Fair & Poor \\
\hline 1 single dose & 76 & 18 & 6 \\
Divided doses & 78 & 14 & 8 \\
\hline
\end{tabular}

\section{Sedation}

Sedation was recorded $0-5$ as with analgesia. With ideal, grade 3 , sedation the patient slept until addressed, whereupon he performed accurately and at once. Table VI summarizes the results. 
Factors affecting sedation were reviewed. Advancing age and severity of disease clearly led to greater sedation. In four cases only was it severe enough to add difficulties to the co-operation of the patient. It was unrelated to both the method of narcotic administration, and the dosage of narcotic used. There was a slight suggestion that sedation was greater with haloperidol than with the same dosage of droperidol, but with increasing dosage of the latter, sedation improved.

TABI.E VI

Sedation: 53 Stereotactic Procedures

\begin{tabular}{cc}
\hline Grade & No. of cases \\
\hline 5 & 4 \\
4 & 7 \\
\hline 3 & 14 \\
\hline 2 & 10 \\
1 & 10 \\
0 & 8 \\
\hline
\end{tabular}

TABLE VII

Respiratory Depression and Phenoperinine Dosage

\begin{tabular}{lcccc}
\hline & \multicolumn{3}{c}{$\%$ patients with: } \\
\cline { 2 - 4 } & $0 \%$ fall & $0-30 \%$ fall & Over $30 \%$ fall \\
\hline Single initial dose & 12 & 29 & 59 \\
Divided dose & 50 & 25 & 25 \\
\hline
\end{tabular}

\section{Amnesia}

Though few patients had total amnesia, most could later recall only isolated incidents during the operation.

\section{Respiratory Depression}

In common with all narcotics, phenoperidine causes respiratory depression. This depression was particularly evident in patients over 60 years of age, and in those with advanced disease. Respiratory depression never constituted a problem, since even a severely depressed patient will breathe at a normal rate if instructed to draw his breath. Narcotic antagonists were found unnecessary after occasional use in early cases. The use of a divided dosage of phenoperidine reduced the incidence of respiratory depression as shown in Table $\mathbb{V I I}$.

\section{Other Effects}

Most neuroleptics in current use induce dyskinetic symptoms when given in sufficient doses to certain individuals. In none of the patients in this study were such symptoms induced, though pre-existing Parkinsonian rigidity was temporarily aggravated slightly during the procedure in 25 per cent $(9 / 36)$ of patients receiving haloperidol, and in 41 per cent $(7 / 17)$ of patients receiving droperidol. Postoperative psychic disturbances, such as have been described after the use of 
haloperidol, were not seen, though transient mental disturbances are occasionally encountered following stereoencephalotomy.

Pulse rate and rhythm and blood pressure showed no trend during these procedures, as often rising slightly as falling slightly, and frequently showing no change. Slight fingernail cyanosis was seen three times; laryngospasm was not encountered. Nausea and vomiting never occurred prior to the performance of the air study, and supplemental droperidol may reduce its incidence at this time.

\section{SUMMARY}

A modified neuroleptanalgesia technique, obviatipg endotracheal intubation, using haloperidol or droperidol and phenoperidine, is described. With this technique 80 per cent of patients undergoing stereotactic procedures showed striking analgesia, while fewer than 10 per cent developed sedation severe enough to interfere with the operation. Factors affecting analgesia and sedation were examined, and side-effects studied.

\section{RÉSUMÉ}

Certaines interventions chirurgicales telles que la stéréo-encéphalotomie, qui requièrent la collaboration du malade, peuvent être très désagréables malgré l'anesthésie locale. Pour obvier à cet inconvénient, nous avons adopté une technique de neuroleptanalgésie modifiée; cette technique consiste à donner assez de narcotique pour compléter l'analgésie sans produire une dépression respiratoire suffisante pour motiver l'intubation endotrachéale.

On a utilisé l'halopéridol ou le dropéridol, avec phénopéridine, pour 14 artériographies carotidiennes consécutives et pour 53 interventions stéréotactiques consécutives; cette technique a été appliquée à des malades d'âge et d'incapacité très variés. Après les premières expériences, nous avons adopté le dosage décrit dans le tableau II.

Aves ce dosage, la moitié des malades a bénéficié d'une excellente analgésie, et un quart a bénéficié d'une bonne analgésie. Une sédation idéale (le malade qui sommeille si on ne le questionne pas et qui coopère lorsqu'on le lui demande) a été obtenue chez 25 pour cent des malades; l'autre 25 pour cent a bénéficié d'une sédation bónne mais moins profonde. La plupart des malades ont presque tout oublié de l'intervention.

Quatre malades seulement ont eu une sédation trop prononcée.

La dépression respiratoire, plus marquée chez les malades âgés, n'a jamais constitué un problème sérieux. Cependant, on pouvait la diminuer en administrant la phénopéridine à doses fractionnées, sans que le degré d'analgésie en soit affecté. Nous n'avons pas eu d'autres inconvénients importants.

\section{REFERENCES}

1. De Castro, J., \& Mundeleer, P. Anesthésie sans barbituriques. La neuroleptanalgésie. Anesth. \& Analg. 16: 1022 (1959).

2. Nilsson, E., \& JANSsEN, P. Neurolept-analgesia-An Alternative to General Anaesthesia. Acta Anaesth. Scandinav. 5: 73-84 (1961).

3. Janssen, P. A. J. A Review of the Chemical Features Associated with Strong Morphinelike Activity. Brit. J. Anaesth. 34: 260-268 (1962). 